University of Rhode Island

DigitalCommons@URI

Open Access Master's Theses

1999

\title{
THE LINKS BETWEEN THEORY AND PRACTICE: COMMUNITY \\ EMPOWERMENT AND THE UNIVERSITY OF RHODE ISLAND \\ WOODLAWN COMMUNITY PARTNERSHIP (COPC)
}

Christopher V. Hawkins

University of Rhode Island

Follow this and additional works at: https://digitalcommons.uri.edu/theses

\section{Recommended Citation}

Hawkins, Christopher V., "THE LINKS BETWEEN THEORY AND PRACTICE: COMMUNITY EMPOWERMENT AND THE UNIVERSITY OF RHODE ISLAND WOODLAWN COMMUNITY PARTNERSHIP (COPC)" (1999).

Open Access Master's Theses. Paper 406.

https://digitalcommons.uri.edu/theses/406

This Thesis is brought to you for free and open access by DigitalCommons@URI. It has been accepted for inclusion in Open Access Master's Theses by an authorized administrator of DigitalCommons@URI. For more information, please contact digitalcommons-group@uri.edu. 
MASTER OF COMMUNITY PLANNING

RESEARCH PROJECT

OF

CHRISTOPHER V. HAWKINS

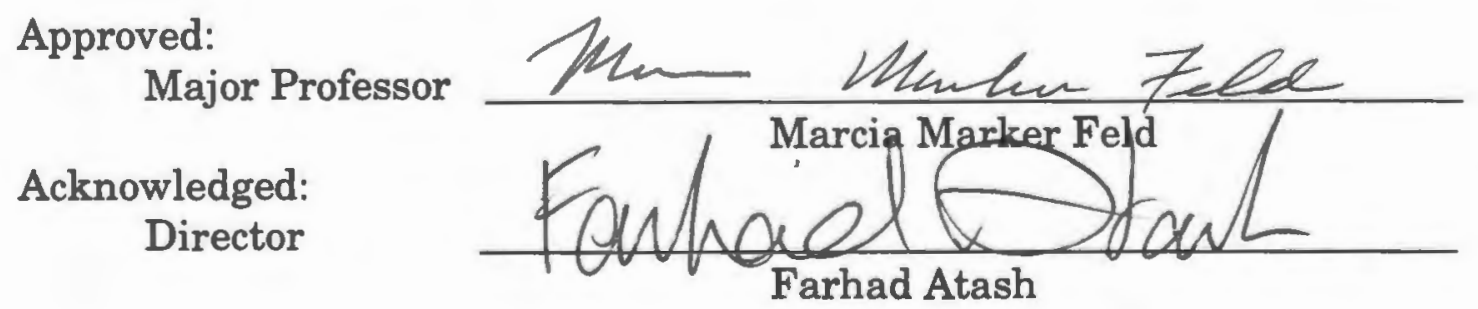




\title{
THE LINKS BETWEEN THEORY AND PRACTICE: COMMUNITY EMPOWERMENT AND THE UNIVERSITY OF RHODE ISLAND WOODLAWN COMMUNITY PARTNERSHIP (COPC)
}

\author{
BY \\ CHRISTOPHER V. HAWKINS
}

A RESEARCH PROJECT SUBMITTED IN PARTIAL FULFILLMENT OF THE REQUIREMENTS FOR THE DEGREE OF MASTER OF COMMUNITY PLANNING

UNIVERSITY OF RHODE ISLAND KINGSTON, RHODE ISLAND 


\section{TABLE OF CONTENTS}

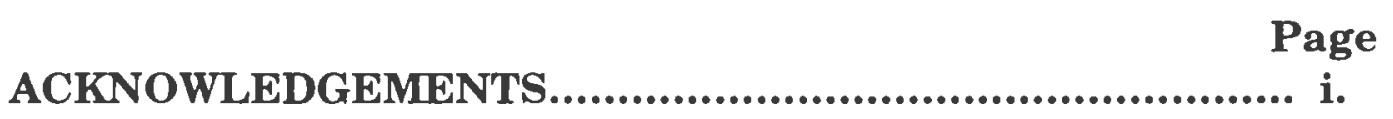

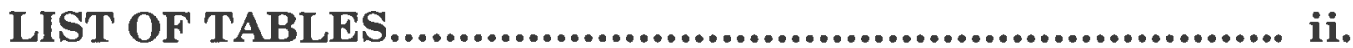

LIST OF FIGURES.................................................. iii.

\section{CHAPTER ONE}

An Introduction To Community Empowerment

And The URI/Woodlawn Community Partnership (COPC)

Introduction............................................................. 1

Review of the Literature................................................7

Organization of the Research......................................... 12

\section{CHAPTER TWO}

Theory And Practice:

The URI/Woodlawn Community Partnership (COPC)

Introduction.......................................................... 14

Description of the Woodlawn Neighborhood...................... 14

The Woodlawn/URI COPC Partnership............................ 18

Structure of the Woodlawn COPC................................... 23

Planning in the Postmodern Environment....................... 25

The Link Between Theory and Practice:

Community Empowerment......................................... 29

Summary ........................................................... 33

\section{CHAPTER THREE}

Systems Analysis:

The Transfer Of Knowledge In The Partnership

Introduction............................................................... 34

Description of Systems Analysis...................................... 35

Analysis of COPC with Systems Analysis........................ 39

Summary ............................................................. 42 
CHAPTER FOUR

Woodlawn COPC Subcommittee Activities

Introduction............................................................ 44

Housing Activities.................................................... 45

Planning and Neighborhood Revitalization Activities........... 49

Education Activities................................................... 52

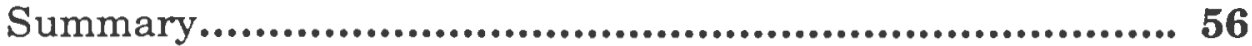

\section{CHAPTER FIVE:}

Community Empowerment As A Strategy Of Planned Change: An Analysis Of The Woodlawn COPC Subcommittee Activities

Introduction......................................................... $\quad 57$

Analysis of Housing Activities...................................... $\quad 59$

Analysis of Planning and

Neighborhood Revitalization Activities......................... 61

Analysis of Education Activities..................................... $\quad 62$

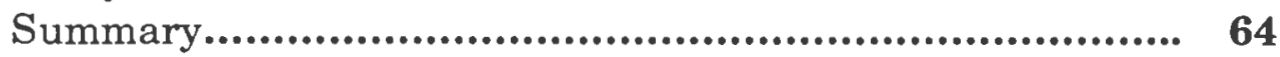

CHAPTER SIX:

Conclusion: Community Empowerment As A

Link Between Theory and Practice

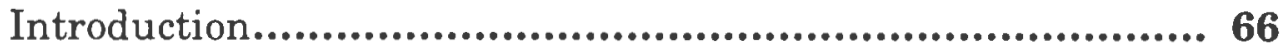

Findings................................................................. 67

Summary ............................................................ 71

Works Cited .............................................................. 73 


\section{ACKNOLWEDGMENTS}

I would like to thank first and foremost Professor Marcia Feld.

She has been an inspiration to me, both in the classroom and in the work environment. I would not fully understand what it means to be a planner if it where not for her guidance and insight. I would also like to extend my thanks to Dr. Mark Motte, who pointed me in the right direction while I was an undergraduate, and Gayla Gazerro, of which this project is the culmination of my work with her. She has been a true friend.

Thanks are also extended to

the rest of the faculty at CPAD, especially Dr. Farhad Atash, as well as my classmates; Owen O'Neil, Keith Brynes,

Erik Beach, Scott McPartlin and Ben Hartly.

Special thanks also to Will, Dave, Missy, and Sue for their support during my last year in planning school. 


\section{LIST OF TABLES}

Table $2.1 \quad$ Page

Unemployment Rates: Woodlawn, RI, U.S. ......................... 15

Table 2.2

Median Household Income: Woodlawn, Pawtucket.................. 16

Table 2.3

Population Change: Woodlawn, Pawtucket........................... 16

Table 2.4

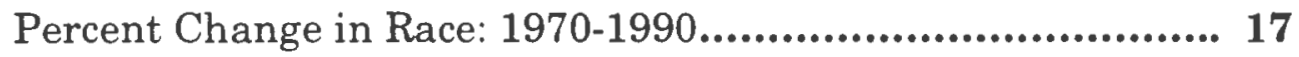

Table 2.5

Percent of Persons Age 25 and Older with a

High School Diploma...................................................... 17 


\section{LIST OF FIGURES}

Figure One $\quad$ Page

Woodlawn COPC Partners............................................ 19

Figure Two

Woodlawn COPC Resources........................................ 22 


\section{CHAPTER ONE \\ An Introduction to Community Empowerment \\ And The URI/Woodlawn Community Partnership}

\section{Introduction}

In 1992, the U.S. Department of Housing and Community Development (HUD) created the Office of University Partnerships. This office is responsible for funding and overseeing the over 180 University-Community Partnerships around the country. University-Community Partnerships where developed in response to the issues that plague many American cities, such as poverty, decay, and disinvestment. They were specifically developed to tap the resources of higher education to facilitate the revitalization of these areas. The UniversityCommunity Partnership initiative was designed to link together the assets of both university and community to address urban problems through planned social change.

Planned change as defined by Bennis, Benne, and Chin (1976), is a process that takes place through the deliberate and conscious utilization of valid and appropriate knowledge. The sources of this valid knowledge are citizens, practitioners, academics, and professionals. Planned change requires a collaborative effort between persons with knowledge and persons of action. The task of the planner, as a change agent in this process, is to create linkages between differing and sometimes conflicting groups toward collaboration (Bennis, Benne and Chin, 1976). The change agent operates within typological constructs of strategies of planned change. The three way classification of the 
strategies for change, as outlined by Bennis, Benne and Chin, include the (1) normative re-educative model (2) rational empirical model, and (3) power coercive model. Under the normative re-educative model of planned change, the role of the change agent is of a facilitator and mediator. Theory and knowledge are legitimized in a collaborative model, and the transfer of information as knowledge takes place through capacity building and empowerment (Bennis, Benne, and Chin, 1976).

The central theme of this thesis project is to study community empowerment, both as a process and as an outcome. This research explores community empowerment within two contexts; (1) within the normative reeducative model of planned change and (2) within the context of a collaborative effort between practitioners, researchers, and stakeholders, that emphasizes this re-defined relationship between stakeholder and change agent. The focus of this research will be an assessment of the collaborative effort between the partners in the Community Outreach Partnership Center (COPC), formally known as the URI/Woodlawn Community Partnership (Woodlawn COPC). Through this, an exploration of the stakeholder and change agent relationship within this partnership is explored, as is community empowerment as a strategy of planned change and an examination of the link between theory and practice.

Using the activities of the Woodlawn COPC, an examination of community empowerment and the link between theory and practice has been undertaken. This research is framed by the strains and themes of the 
postmodern approach to planning: a new emphasis on communication, language, and collaboration (Forester, 1989); an expansion of the sources of knowledge (Forester, 1989; Innes, 1990; and Nyden, 1997); the limits of technical rationality and a new mode of contextual learning, as well as strategies of dissemination of knowledge (Beauregard, 1989; 1991 Innes, 1990; Shoen, 1982) and approaches to gaining knowledge (Park, 1993); an emergence of interpersonal and communicative theory of planning (Shoen, 1982); an interpretive framework of knowledge rather than a positivist view of knowledge (Innes, 1990; Forester, 1989); and a concept of knowledge that expands it to socially shared beliefs and contextual settings (Innes, 1990).

The rational planning technique has wuen the organizing principle by which planning decisions are made, actions organized, and implementation carried out since post WW II. It is the basic covenant of the "modernist project" (Beauregard, 1989). The modern planning approach encompasses procedures and methods based on this rational decision making process, which orders human affairs and actions and where the process of change can be shaped and directed (Beauregard, 1989). Christopher Paris writes that planning is "no more and no less than all conscious attempts to organize action in order to affect future outcomes" (Paris, 1982 pg. 6). The planning process is grounded in rationality, the benefits of which are increased capacity to learn and be creative (Thomas, 1982). Society is deciding in a rational way, controlling its activities and future by relying on methods of a logical sequential process. However, the 
rational activities of the modern paradigm do nothing to elaborate on the position of planning, as a process and occupation, within the environment in which it operates (Paris, 1982).

The postmodern paradigm developed in part as a reaction to the assumptions of the rational planning model. The framework of the postmodern paradigm is distinctly different than the foundations of rational planning in that it recognizes the planner's limited resources, such as time, funding, and information, and it holds that science and factual information alone is not determinative of policy decisions. The collective action to direct human affairs under the direction of a single text is undermined by the postmodern condition. A higher collective interest is replaced with a state of uncertainty and ambiguity where communication is the key to decisions. It is an environment of plural voices and multiple discourse between competing thoughts, interests, and prerogatives of various groups. (Beauregard, 1991; Forester, 1989; Mandelbaum, 1991; Milroy, 1991). It is this context that the change agent intervenes in the process of planned change.

The postmodern planning environment presents challenges for planned change: uncertainty, complexity, plurality, and turbulence. It poses problems of issue identification, consensus building, and goal setting within a turbulent political environment. This raises the question, how is planned change (the normative re-educative task of the change agent) implemented within this 
postmodern planning environment? Given this framework, how is planned social change effective?

This thesis project seeks to examine the link between theory and practice illustrated by the activities of the URI/Woodlawn Community Partnership (Woodlawn COPC). Community empowerment, as a response to the environment which is created by the postmodern approach to planning, is a strategy of planned change that is reflected in the activities of the Woodlawn COPC. These activities will be analyzed with reference to (1) participatory research, (2) information transfer and dissemination, and (3) resource outreach. The purpose of this research is to demonstrate how the problems of the postmodern approach to planning have been met by the processes and outcomes of community empowerment. This research will indicate how planned social change can be accomplished within this environment.

This paper specifically explores the Woodlawn COPC in the context of this "new" postmodern approach to planning and planned social change. It will explore these new sources of knowledge, the new role of the planner as a change agent, and community empowerment as a strategy for change. The link between theory and practice that is analyzed in this research conforms to the view that the master narrative is not the sole mechanism for planned change, but rather, there is a multiple discourse involving a plurality of voices. Beauregard writes, the "modernist planning project" has failed; the demise of the master narrative, the bankruptcy of positivism, and the political influence of the technical expert 
(Beauregard, 1989). A new role of the change agent has emerged; one who is a facilitator, mediator, and translator in a paradigm that emphasizes a new definition and source of knowledge, a new use of knowledge, and a new link between knowledge and action.

The role of the change agent within the postmodern paradigm links theory to action with ethical concern, and focuses on facilitating and mediating the process of change. This is a clear departure from the rational model of the modern paradigm. The change agent is part of the process in a system of interdependencies within geographical and political boundaries. How information becomes knowledge, how this knowledge becomes valid, and the role of the change agent within this system, will be conceptualized using systems analysis. The structure of the power and authority within this collaborative effort of the Woodlawn COPC will be explored. In order to assess the findings, the provision, distribution, and legitimization of information will be explored as well. The question to which this research is partly addressed is: what knowledge is transferred, to whom, and by whom, and how this contributes to community empowerment? 


\section{A Review of the Literature}

The recent literature on community empowerment theory, research, and intervention has been applied to a wide variety of disciplines for analysis. The central themes of empowerment as a construct, however, have remained; social change that links the individual and larger societal units together in the context of creating a healthy and responsive community (Perkins and Zimmerman 1995). The health profession, especially psychology disciplines, have added to the literature on community empowerment and its place in the process of planned change; workplace empowerment (Spreitzer, 1992; 1995); health promotion (McMillan, Florin, Stevenson, and Mitchell 1995; coalition building (Fawcett el al., 1995; Maton and Salem, 1995; McMillan et. al., 1995); environmental action (Rich, Edelstein, Hollman, and Gooderson, 1995) community empowerment theory (Zimmerman, 1993; Zimmerman, 1995; Zimmerman, Isreal, Schulz and Checkoway, 1992; Israel, Schulz, Checkoway, and Zimmerman, 1994); and empowerment and its relation to economic development (Wilson, 1996). Empowerment, as Wilson has used the construct, is a bridge. It is a synthesizing term that brings together individualistic and societal change (Wilson, 1996).

The health profession's research on empowerment emphasizes the use of inter-organizational support systems and models of empowerment grounded in collaboration and coalition building. It expands on the literature of planned change exemplified by Bennis, Benne, and Chin (Bennis, Benne, Chin, 1976). 
They built a conceptual framework of organizational interaction and theory that emphasizes the exchange of information. It also is based on the literature outside the field of economic inter-organizational analysis; the concept of “organization set" (William Evan, 1966), the study of inter-organizational relations between agencies, specifically the health and welfare agencies (Levine and White, 1961), coordination between these agencies (Litwak and Hylton, 1962), and goal setting and its relation to the interdependence of organizations within larger society (Thompson and McEwen, 1958). An understanding of the dynamics of the organizational environment itself is vital to the comprehension of inter-organizational theory (Bennis, Benne and Chin, 1976).

A necessary part of change involves support networks, systems, and organizational relations. A function of those support networks is to empower people with an emphasis on the participation of those that it affects by the creation of organizations and the utilization of existing systems (Bennis, Benne and Chin, 1976). Varying approaches to building support and gaining an understanding of factors which impede this process are examined: Culbert's "Consciousness-Raising" (Culbert, 1975), Gilbert and Eaton "Who speaks for the poor?" (Gilbert and Eaton, 1970), and Lisa Peattie's "Drama and Advocacy Planning" (Peattie, 1970).

Crowfoot and Chesler (Crowfoot and Chesler, 1974) group planned social change into three perspectives. These include; the "professional - technical perspective" (Bennis, Benne, and Chin, 1976; Argryis, 1962; Likert, 1961; 
Lippitt, 1958; Schein, 1969; Watson, 1966; and Zetterberg, 1962); the "political" (Bennis, Benne, and Chin, 1969, 1976; Alinsky, 1969; Carmichael and Hamilton, 1967; Gamson, 1968; Kahn, 1970); and "grass-roots" (Bennis, Benne, and Chin 1969 and 1976; Buber, 1949; Fairfield, 1972; Fromm, 1955; Nearing and Nearing, 1970; Schutz, 1971; Slater, 1970).

The emphasis on community empowerment as a construct is in the context of collaborative partnerships, and establishing inter-organizational networks that foster citizen participation and improvements to community life (Perkins and Zimmerman, 1995; Butterfoss, et al., 1993; Chavis and Florin, 1990; Fawcett, Paine, Francisco, and Viet, 1993). Community empowerment has come to be recognized as a process, with an emphasis on community participation and resource mobilization through coalition building and collaboration. It has also been recognized as an outcome with the institutionalization of organizations and networks, and the establishment of citizen leadership with the result of community understanding of these systems (Perkins and Zimmerman, 1995; Zimmerman, 1995; Zimmerman 1993; Swift and Levine, 1987; Chavis and Wadersman, 1990). Empowerment has been emphasized as a process of gaining influence over a community by people who share experiences or workplaces, and have similar problems, issues, or concerns (Fawcett et al., 1995; Rappaport, 1981). It involves a multifaceted organizational approach to mobilize and stimulate change through participatory 
and collaborative workings, facilitated by models of community empowerment (Fawcett et. al., 1995; Perkins and Zimmerman ,1995; McMillan, 1995).

The empowerment model advocated by Fawcett emphasizes these partnerships through networks and support mechanisms as part of a multifaceted approach involving various institutions such as universities and outreach organizations (Fawcett et al. 1995; Chavis et al., 1993; McArthy and Zald, 1977; Gray, 1991; Wolff, 1992; Sarason and Lorentz 1979; Mondros and Wilson, 1994), and involves the participation of community members and their leadership activities (Fawcett et al., 1995). The collaborative empowerment framework outlined by Fawcett has five interrelated elements: collaborative planning; community action; community change; community capacity and outcomes; adaptation, renewal, and institutionalization (Fawcett et al.,1995). Partnerships in this empowerment framework emphasize the process of empowerment through facilitating leadership in communities with support organizations that promote community improvement (Gabor, 1990; Weick, 1984), and in doing so, acts as an assessment tool used as a way to understand the strengths and weaknesses of the community (Weick, 1984).

Issues concerning the sustainability and effectiveness of community empowerment initiatives, and the role that professionals and the various organizations play in the process of empowerment, are also criticized and questioned (Labonte, 1994; Potapchuk, 1996). Although empowerment initiatives are mostly dealt within the context of a larger society, with the 
inclusion of various institutions and organizations and the active participation of community members in the process of planned change, (Wallerstein and Bernstein, 1994), case studies that focus on the measurement of empowerment and community competence, and defining the relationships between people and organizations involved in empowerment (Israel, Checkoway, Schulz, and Zimmerman, 1994; Eng and Parker, 1994); as well as looking at the problems experienced in partnerships between broad based community, government, and social service agencies in community empowerment plans (Plaugh and Olafson, 1994); the processes of including various organizations and the issues that are faced (Eiser, 1994). An analysis of why some communities organize at the grassroots level and why some do not (Perkins and Brown, 1996) has also supplemented the literature on community empowerment. 


\section{Organization of the Research}

This thesis research project begins with a profile of the Woodlawn neighborhood in Chapter Two. Specifically, it provides a contextual setting of the issues faced by Woodlawn residents. Then, this chapter describes the partners in the Woodlawn COPC. This chapter continues by addressing the theoretical framework within which the change agent operates. The postmodern planning paradigm is briefly outlined and described in this section. Lastly, Chapter Two explores community empowerment as the conceptual link between theory and practice.

The literature on community empowerment focuses on community partnerships and collaboration, systems of interdependencies and organizational relations. Chapter Two draws upon this literature to demonstrate how community empowerment can be a bridge between the paradigm that planners work within, and the activities that are facilitated by the planner as a change agent. The Woodlawn COPC is explained as a model of how community empowerment can be used as a tool to achieve planned social change.

Chapter Three examines more closely the link between the theory of interorganizational systems and the practice of planned social change as demonstrated in the Woodlawn COPC. This chapter first explores the meaning and approach of systems analysis. Second, this chapter details and examines the structure of COPC in relation to the conceptual framework of systems 
analysis. Third, this chapter analyzes the Woodlawn COPC in reference to systems analysis.

Chapter Four describes the activities of the Woodlawn COPC as an illustration of community empowerment. In particular, the activities of the Housing Subcommittee, Education Subcommittee, and Planning and Revitalization Subcommittee are detailed.

Chapter Five is an analytical look at the activities of the Woodlawn COPC subcommittees. This analysis focuses on these activities with reference to community empowerment, specifically, participatory research, information transfer and dissemination and resource outreach. The chapter explores the role of the change agent within the normative re-educative model of planned social change. How the change agent facilitates planned social change, and the function of the change agent in the Woodlawn COPC, are questions to be addressed.

Chapter six is a summary of the findings of the research assessing community empowerment as a link between the theory of planning and the planning action of the Woodlawn COPC. The research will respond to the following questions:

- "How well has the COPC facilitated community empowerment?"

- "Has the Woodlawn COPC met its goal of community empowerment?"

- "Is the COPC a successful model of planned social change?" 


\section{CHAPTER TWO \\ Theory And Practice: The URI/Woodlawn Community Partnership (COPC)}

\section{Introduction}

The fundamental assumption in this research project is that collaboration in community partnerships is an effective mechanism to achieve planned social change. The Woodlawn COPC is a model of this approach which facilitates community empowerment and neighborhood revitalization through community partnerships. This chapter provides a profile of the Woodlawn neighborhood and the Woodlawn COPC. It also briefly explains the postmodern planning paradigm and explores community empowerment as a link between theory and practice.

\section{Description of the Woodlawn Neighborhood}

The Woodlawn neighborhood is located in the City of Pawtucket, RI. It is comprised of census tracts $151,152,161$, and 164 , and is the second largest of the ten neighborhoods in Pawtucket. Like the City of Pawtucket, the Woodlawn neighborhood reflects the transition that many older urban centers have undergone. High unemployment and an aging housing stock are just two challenges the Woodlawn neighborhood faces as it moves ahead with plans for revitalization. The Woodlawn revitalization approach is an inclusive one which addresses a number of issues such as low educational attainment and high rates of poverty; absentee landlords; increasing home ownership; decline of local business; and economic prosperity. 
Pawtucket had once prospered as a manufacturing center. In the last few decades, however, the city has undergone significant economic and social changes. As the manufacturing industry declined nationally, Pawtucket also experienced job loss and disinvestment. Large jewelry manufacturers and downtown retailers slowly closed in the wake of foreign competition and suburban malls. Some manufacturers have remained and continue to operate in Woodlawn, but unemployment has plagued the neighborhood in recent years (Table 2.1).

Table 2.1: Unemployment Rates, Woodlawn, Pawtucket, RI, and U.S.

\begin{tabular}{lrrr} 
& $\mathbf{1 9 7 0}$ & $\mathbf{1 9 8 0}$ & $\mathbf{1 9 9 0}$ \\
\hline United States & 6.6 & 6.4 & 6.3 \\
Rhode Island & 4 & 7 & 6.6 \\
Pawtucket & 4.1 & 6.8 & 8.4 \\
Woodlawn & 6.5 & 8.9 & 11.4 \\
Source: U.S. Census: $1970,1980,1990$ & &
\end{tabular}

The Woodlawn neighborhood is one of the more economically depressed areas of Pawtucket. The median family income is $\$ 25,563$. This has been historically lower than the median income of both the City of Pawtucket and the State of Rhode Island (Table 2.3). Approximately $61 \%$ of the population have a low to moderate income, and $18 \%$ of the persons in Woodlawn live under the federal poverty level. This includes $26 \%$ of children under the age of six. 
Table 2.2: Median Bousehold Income, Woodlawn, Pawtucket, RI

\begin{tabular}{lrrr} 
& $\mathbf{1 9 7 0}$ & $\mathbf{1 9 8 0}$ & $\mathbf{1 9 9 0}$ \\
\hline Woodlawn & 6,890 & $\mathbf{1 2 , 4 8 7}$ & 25,563 \\
Pawtucket & 9,265 & 17,407 & 33,679 \\
Rhode Island & 6,062 & 19,448 & 39,172
\end{tabular}

Source: U.S. Census: $1970,1980,1990$

Similar to other urban areas, the social fabric of Pawtucket has also undergone change. The Woodlawn neighborhood is indicative of this transition. As table 2.3 displays, the population of Woodlawn had increased $4.0 \%$ between 1970 and 1990 while Pawtucket experienced a $6.0 \%$ decline in population. The population increases are due, in part, to the changing demographic character of the neighborhood. Table 2.4 represents the racial and ethnic change of the population. The population of white persons has decreased by $31.5 \%$, while the population of black persons now represents nearly $9 \%$ of the total population. Persons of Hispanic origin have also increased in population, and now represent $14.5 \%$ of the total population. This is up from $7.1 \%$ in 1980 . Half of the population in Woodlawn speaks a language other than English, as compared to $25 \%$ for the city as a whole. The predominant languages spoken are English, Creole/Portuguese, and Spanish.

Table 2.3: Population Change, Woodlawn, Pawtucket, RI

\begin{tabular}{lcrrr} 
& & & \multicolumn{1}{c}{$\%$ change } \\
& $\mathbf{1 9 7 0}$ & $\mathbf{1 9 8 0}$ & $\mathbf{1 9 9 0}$ & $\mathbf{1 9 7 0 - 9 0}$ \\
\hline Woodlawn & 15,813 & 15,617 & 16,471 & 4.0 \\
Pawtucket & $\mathbf{7 6 , 9 8 4}$ & 71,204 & 72.644 & -6.0 \\
Rhode Island & 946,725 & 947,154 & $1.003,400$ & 5.6
\end{tabular}


Table 2.4: Percent Change in Race, 1970-90

\begin{tabular}{lrrrrrrr} 
& 1970 & $\%$ & 1980 & $\%$ & 1990 & $\%$ & $\begin{array}{c}\% \text { change } \\
\mathbf{7 0 - 9 0}\end{array}$ \\
\hline White & 15,166 & 96.0 & 13,730 & 88.0 & 11,530 & 70.0 & -31.5 \\
Black & 89 & 0.6 & 474 & 3.0 & 1,439 & 8.7 & 93.8 \\
Hispanic Origin & 313 & 2.0 & 1,115 & 7.1 & 2,395 & 14.5 & 86.9 \\
Source: U.S. Census: $1970,1980,1990$ & & & & & &
\end{tabular}

Table 2.5 displays the percent of persons age 25 and older with a high school diploma. Although this percent has steadily increased to $44.8 \%$ in 1990 , it remains below both the city and the state.

Table 2.5: Percent of Persons Age 25 and Older with a High School Diploma

\begin{tabular}{lrrr} 
& $\mathbf{1 9 7 0}$ & $\mathbf{1 9 8 0}$ & $\mathbf{1 9 9 0}$ \\
\hline Woodlawn & 25.4 & 35.7 & 44.8 \\
Pawtucket & 37.8 & 49.8 & 61.6 \\
Rhode Island & 46.4 & 61.1 & 66.7
\end{tabular}

Source: U.S. Census: 1970, 1980, 1990

The activities and plans for the revitalization of the Woodlawn neighborhood have been initiated to address these and other issues. These initiatives are part of an innovative approach to community revitalization that focuses on community engagement and empowerment. The revitalization of the Woodlawn neighborhood is not purely a physical undertaking, but is a holistic approach that includes activities and plans that provide outreach to the community and research with local residents and agencies. In the wake of economic transition and social change, the issues that face Woodlawn are 
numerous and diverse. The Woodlawn Community Outreach Partnership Center (COPC) utilizes the resources in the community and higher education and builds partnerships that identify specific issues and develop revitalization activities and plans that focus on these concerns. 
The Woodlawn/URI COPC Partnership

The Woodlawn Community Outreach Partnership Center (Woodlawn COPC) was created to facilitate the revitalization of the Woodlawn neighborhood through the collaboration of community residents, and existing community resources and supporting institutions. This collaboration involves universities, community groups, local government, social service agencies, public schools, and public housing. Together, with the direct involvement of neighborhood groups and local residents as participants, leaders, and coordinators, the Woodlawn COPC facilitates change in Woodlawn by operating as a center for information exchange and knowledge transmission between these partners. The activities of the Woodlawn COPC are grounded in community empowerment based on the utilization and exchange of valid and appropriate knowledge. The exchange of this knowledge, as a strategy of planned change, is validated by the direct inclusion of area residents. Joint community-based research between the COPC partners and resource dissemination and information exchange between area residents, experts, professionals, and practitioners from universities, community, and local government are the cornerstones of the Woodlawn COPC initiative (see figure 1). 
Figure One

Woodlawn COPC

COPC Partners

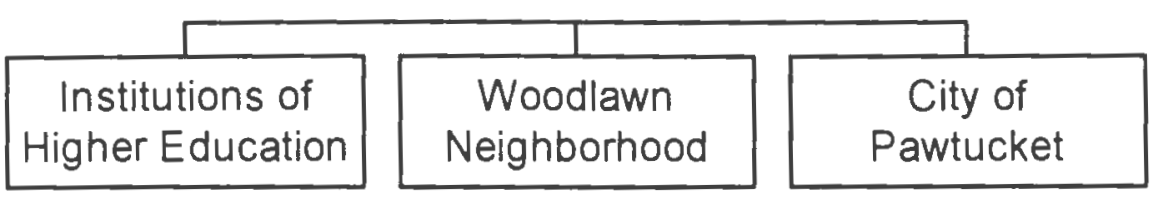

The research that involves the joint participation among the partners of the COPC, and the activities that facilitate information exchange, provide new sources of knowledge and outreach that build on citizen empowerment, are staffed by the University of Rhode Island Urban Field Center (URI UFC). The URI UFC facilitates planned change with these activities and collaborative undertakings by implementing capacity and leadership training for residents, and developing public service projects and instructional programs that seek to empower residents of the Woodlawn neighborhood. The URI UFC is demonstrative of the normative re-educative role of a change agent. It acts in a facilitating role by linking knowledge and action through building the capacity of the stakeholders through community empowerment, and bringing together persons of knowledge and persons of action.

The URI UFC is the outreach and applied research arm of the Graduate Department in Community Planning at the University of Rhode Island. In addition to the direct role the Department of Community Planning plays in the 
Partnership, the URI UFC and the Woodlawn COPC rely on other resources of the University of Rhode Island. These other resources include: Rhode Island Cooperative Extension; Department of Landscape Architecture; and the Service Learning Project. The activities that the COPC undertakes are matched with these University resources. Other University Partners include The Roger Williams Law School and the Rhode Island School of Design.

This collaborative effort also involves a number of government departments, community agencies, Woodlawn residents, and institutions and support networks: the Woodlawn Neighborhood Association; Blackstone Valley Community Action Program, and Cape Verdean American Community Development Corporation. The Pawtucket Citizens Development Corporation, the Office of the Mayor, the Pawtucket Department of Planning and Redevelopment, the Pawtucket Recreation Department, the Pawtucket Public Housing Authority, the Pawtucket Public School Department and the Cunnigham/Slater Child Opportunity Zone/Family Center. These are all partners in the Woodlawn COPC (see figure 2).

Together, the URI UFC, the Community Development Office of the City of Pawtucket, and the Woodlawn community, have identified three functional areas that are to be addressed: Housing, Planning and Neighborhood Revitalization, and Education and Social Services. The issues in these three categories are addressed by activities that engage the community and are aimed at empowering and building capacity of Woodlawn residents. The revitalization 
efforts are an inclusive approach grounded in collaboration where the change agent facilitates the sharing of resources and the transfer of knowledge to address the issues that were self-identified by community direction. Residents of Woodlawn are a key component in the process of problem identification and the development of revitalization strategies. Through a collaborative process, community residents play an active role as leaders and jointly participate to define problems, guide the activities and programs of the COPC, and develop, implement, and review revitalization strategies.

Figure Two:

Woodlawn COPC Resources

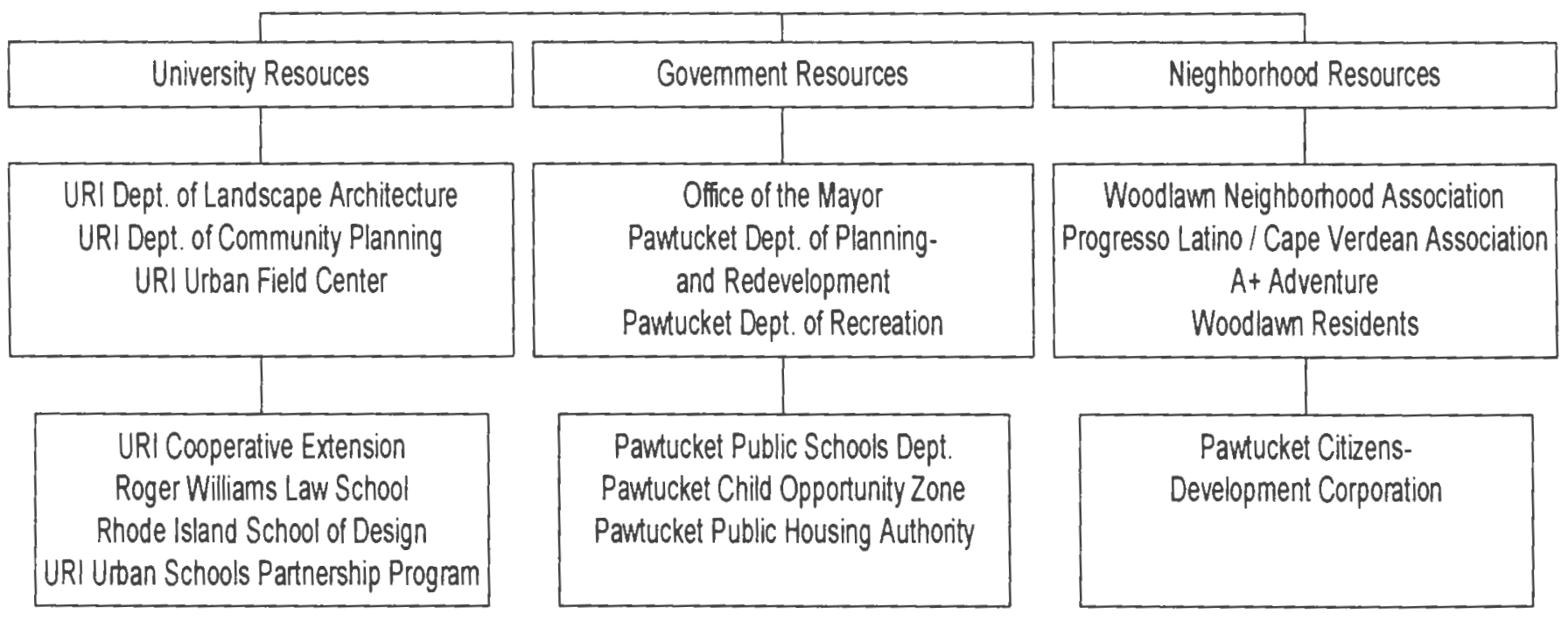




\section{The structure of the Woodlawn COPC}

The governing structure of the Woodlawn COPC is organized to maximize participation of COPC partners as well as empowerment of residents. The Woodlawn COPC is organized into various committees. The executive committee oversees the activities of the COPC and includes representatives from the City of Pawtucket, higher education, Woodlawn residents, agencies, and organizations. An Advisory Committee of approximately 175 members was formed which includes residents, university faculty, and organizations and agencies within Pawtucket. Subcommittees on Housing, Planning and Neighborhood Revitalization, and Education/Social Services where developed from the Advisory Committee.

The URI UFC and the City of Pawtucket have joined together to provide the necessary technical and expert knowledge to the COPC and act as staff to the Executive Committee. The URI UFC acts as the facilitator of the Advisory Committee and the three subcommittees. These three subcommittees design activities that address functional areas within each category. Each subcommittee identified needs, problems, issues, and solutions. These where then matched with university resources to create a consortium of partners who utilize their knowledge in the efforts to revitalize Woodlawn. The partnership between universities and the community has created a support network of resources that facilitate community empowerment. 
Community empowerment is supported through the active participation of area residents in the change process. Together with these residents, the URI UFC researches problems, coordinates outreach, exchanges information and resources, creates support structures for neighborhood revitalization projects, develops public service and capacity building projects and instructional programs. Although the URI UFC facilitates this process, through these activities the consortium of COPC members themselves become agents of change. 
Planning in the Postmodern environment

Bennis Benne and Chin in "The Planning of Change" propose that planned change is collaborative and grounded in the application of valid and appropriate knowledge to human affairs (Bennis, Benne, Chin, 1976). Societal organization, viewed as a system of human affairs as interconnected and interdependent components of a pluralistic system, has positioned change agents within a new role in the process of planned change. The postmodern perspective on planning that emphasizes this plurality has undermined the modernist approach, and has ushered in a new dimension in which planned change is implemented. It is, in part, the recognition of new sources of knowledge, and the access to this knowledge in the process of planned change, which has revealed the significance of the postmodern paradigm in planning. This new direction of planning recognizes the plurality of voices and the diversity of the society.

In the planning environment of the modern paradigm, the planner is an expert who could use their knowledge and technical expertise to guide the logistical steps of the project while being disengaged from politics or interest groups. These activities centered around a master narrative - comprehensive rationality (Beauregard, $1989 \mathrm{pg}$. 385). The components of planning as rational techniques were universally applied to the city as a single unit. A single narrative, reducing uncertainty through a logical process of decision-making (Hemmens, 1992) shaped a strategy which was goal oriented and client centered as an approach to problem solving. This characterizes the Modern Paradigm. 
The rational approach of the modern planning paradigm, however, has recently been heavily attacked. It is bounded by limited knowledge of cause and effects, uncertainty about institutions and organizational environment, and their response to planning outcomes, and the difficulty in predicting future values, goals, and objectives in light of accelerating social change (Alexander, 1990). Modernism has disallowed the multiness of society: multi-culturalism, multiracial, gender, space and time, with the use of a single scheme or organizing totalizing discourse (Hemmens, 1992).

Economic transitions to a global economy, and sector shifts in economic activity have increased capital mobility and destabilized the economy. PostFordism production and flexible specialization have influenced the spatial organization of urban areas, altered commuter patterns, and have heightened the social and economic issues in cities. The postmodern environment has altered the assumption that "local actions were determinative of local conditions". The global influence on job creation and retention has been politicized, and competition between localities to increase economic activity has altered local economic development practices. Then, the modernist paradigm and its assumptions did not bring equity or access to class, race, and gender, which are value commitments of the field of planning. The result has been a quest for an unattainable conflict free public interest. (Beauregard, 1989; Harvey, 1990). This transition has produced a marginalized workforce along social lines and an uneven spatial distribution of the labor force and economic 
activity. The master narrative is incompatible with the postmodern urban form (Beauregard, 1989). The responsiveness of planners to issues of equity and access had been overshadowed.

The process of planning within the postmodern condition asserts a new direction for planners. The notion that there is some best choice or action is not attainable since there are multiple, irreconcilable differences within society (Hemmens, 1992). As Harvey comments on this plurality defined by Lyotard as "language games", "cultural life is then viewed as a series of texts intersecting with other texts, producing more texts" (Harvey, 1990 pg. 49). In the modern planning approach, the relation to legitimacy is grounded in meta-discourse; a single narrative and a consensus between rationality of sender and addressee (Lyotard, 1984). This totalizing discourse has been attacked as unrepresentative of the pluralistic society illustrative of diverse social relations.

The legitimacy of planning has been based on the public interest, defined as the aggregation of totality of values in the community, or, an agreed upon set of goals and objectives upon which the rational planning process is expected to work (Alexander, 1990). If this public interest defined through the creation of a single text, which is not attainable within the context of this new planning paradigm, where can legitimacy reside in the postmodern condition? How can decisions be carried out, consensus be formed, and action oriented goals defined given this pluralist discourse among various conflicting groups, stories, contents, and contexts (Lyotard, 1984; Mandelbaum, 1991)? Mandelbaum asks the 
question: "How do planners operate in a pluralist field where a master narrative cannot reveal a single truth from competing stories and conflicting meanings of the world?" The plurality and diversity, and often-incommensurable narratives, poses problems for the change agent facilitating the process of planned change (Mandelbaum, 1991 pg. 213).

Through the activities of the Woodlawn COPC, a single, totalizing discourse or master narrative is replaced by a sense of self-determination and of empowerment of the community. Residents are not told what to do by experts, but are included in the process of planning through participation and leading group meetings and or membership on boards or committees which plan, implement, and guide the activities of the COPC through joint community-based research. The resources that are made available through this Partnership expand the opportunities for residents to increase their knowledge of the environment around them and take control over their destiny. With the provision of valid and appropriate knowledge through exchange and outreach, residents can utilize this information to guide themselves through the environment. Residents can make their voice be heard, and direct changes in their neighborhood. 
The Link Between Theory and Practice: Community Empowerment

Community empowerment is defined as the "process of gaining influence over conditions that matter to people who share neighborhoods, workplaces, experiences, or concerns" (Fawcett 1995 pg. 2). The capacity of local residents to take control over issues is strengthened within a collaborative framework. The exchange of knowledge that contributes to empowerment can be facilitated by partnerships between institutions and organizations, such as the Woodlawn COPC (Fawcett, 1995). Rather than treating the Woodlawn neighborhood as an object to be studied, the Woodlawn COPC URI UFC conducts research and coordinates activities and events with the community to identify the issues and concerns of area residents. The collaboration between the URI UFC and the Woodlawn neighborhood can be viewed as a catalyst for effective change (Fawcett, 1995). The Woodlawn COPC is a model of planned social change that demonstrates the process of community empowerment which is facilitated by the intervention of a change agent.

Empowerment as a construct emphasizes collaboration and participation at the individual level and collective decision-making at the organizational level. At the community level, empowerment may refer to organizational capacity building through collective action to mobilize resources to meet a goal or objective (Perkins and Zimmerman, 1995). These processes of empowerment are evident in the structure and activities of the Woodlawn COPC. The URI UFC, acting as the change agent, not only provides technical assistance, but more 
importantly builds the capacity of those involved in the community partnership by facilitating the creation and supervision of support networks. These enabling systems are an outlet to gain access to resources, mobilize these resources, and to provide a system that fosters an individual's understanding of their environment (Chavis, 1993). One can influence their position in life by gaining control over their situation within this system by utilizing a collaborative network of organizations that have various resources and knowledge. This information can be useful to address particular issues faced by an individual or organization. This may take place through such activities as participatory research or resource outreach.

Given the planning environment of the postmodern paradigm, how is planned change carried out and how can it be effective? If the master-narrative cannot articulate and represent this plurality and multiple discourse, how is the social change agent to operate? Perkins and Zimmerman have define empowerment-oriented intervention as "enhancing wellness while they also aim to ameliorate problems, provide opportunities for participants to develop knowledge and skills, and engage professionals as collaborators instead of authoritative experts" (Perkins and Zimmerman, 1995 pg. 1). Community empowerment can be an effective tool in planned social change. Individual and organizational capacity building through increased knowledge and information exchange, facilitated by collaboration between information holders, can lead to the empowerment of Woodlawn residents. 
Building the capacity of Woodlawn residents through increasing their understanding of the environment is a strategy illustrated in the activities of the Woodlawn COPC. Activities that foster skill development and motivational development can increase the knowledge one needs to take more control over their lives. The opportunity for the exchange of information facilitates the empowerment of Woodlawn residents. These opportunities are supported by the activities of the Woodlawn COPC. The production of knowledge is one function of the COPC. An increased comprehension of social forces, and the ability to act on these forces individually or collectively is a direct result of community empowerment. Community empowerment is not only the production of this knowledge, but is realized through the "experience of engaging in collective social actions" (Park, 1993 pg. 3). Gaining access or knowledge of resources is an effective tool for community residents to participate in research or planning activities often coveted by professionals.

Community empowerment is the link from knowledge to action and theory to practice. The facilitation of the process of knowledge building is one function of the Woodlawn COPC. Knowledge exchange means not only the teaching and learning of technical information in the process of change, but also the inclusion of the knowledge of Woodlawn residents from their experiences and histories. Empowerment is therefore framed by three important strategies of planned change: (1) information dissemination that aims to engage and inform residents, (2) the direct participation of residents in the process of learning, 
developing plans, and implementing activities, and (3) the inclusion of their knowledge with that of the expert in the process of change. The results are that residents understand their environment more completely, and can comprehend how research, outreach and resource mobilization, and community building is conducted. Through this, residents build a sense that one is not helpless but is an important component of change and can contribute to such activities as neighborhood revitalization through action. This is supported through the interorganizational support network of the Woodlawn COPC. 
Summary

Community empowerment is the link between theory and practice. The Woodlawn COPC demonstrates this link. The Woodlawn COPC is a system of multiple partners that provides support in the process of learning. The URI UFC is the planner/change agent staff that facilitates the process of community empowerment by fostering this collaborative network. The postmodern planning approach rejects the rational model of planning. The master-narrative is replaced with a plurality of voices. Individuals can gain influence over their lives and be part of the capacity building process by being empowered. Individuals, communities, or neighborhoods, can be empowered by gaining knowledge as well as being able to share their own knowledge of the world. This is facilitated by the utilization of support systems. The Woodlawn COPC is a model of how community empowerment is a bridge between the theory of the postmodern paradigm and planning practice. 
CHAPTER THREE

Systems Analysis: The Transfer Of Knowledge In The Partnership

Introduction

Support through community collaboration offers resources, tools, and an outlet for participation in directing planning activities. Empowerment is a process of raising the consciousness by obtaining skills and knowledge through participation in the process of planned change. It is an outcome in that it redirects one's position within society. This is a major goal of the COPC.

Through empowerment, people and organizations can take it upon themselves to take control of their lives; identify issues, and effectively address these problems. The change agent facilitates this knowledge transmission by maintaining a collaborative network of community resources and providing responsive technical guidance so that people can re-position themselves within an environment that is, at best, ambiguous and conflict ridden.

This chapter will examine the link between theory and practice through community empowerment as an approach to shape planning activities in the postmodern planning environment. For an analysis of community empowerment to be undertaken, a framework of the Woodlawn COPC is presented. The organizing framework by which decisions are made within this planning environment, where power and authority lies, and who is involved and how, will be explored through the application of system analysis (Bennis, Benne and Chin, 1976). The application of models utilized in systems analysis will be the 
reference by which the organized structure and relationships in the COPC will be analyzed.

Bennis Benne and Chin describe "systems analysis" as a tool that helps the change agent through the process of assessing and intervening in the interdependencies of systems. It can be applied as part of an analysis of the segments of a system such as communication and power. The application of systems analysis will enable a conceptualization of the Woodlawn COPC as a collaborative partnership that includes the change agent within a system of interdependent components. It will enable an organizing framework to be created that will assist in analyzing the transfer of knowledge, and respond to the question of how community empowerment as a strategy of planned change can be carried out within the postmodern paradigm.

\section{Systems Analysis}

Robert Chin, in his article, "The "Utility of System Models and Developmental Models for Practitioners" (Chin, 1976), presents the "systems" model and the "developmental" model as approaches to diagnose opportunities for change within organizations such as the Woodlawn COPC. Systems analysis is a way of constructing a simplified model of human encounters, and in this case of application, an organizational unit including multiple partners. Concepts such as "boundary", "tension and strains", "equilibrium", and "feed back", are used as analytical tools in the systems model to understand and conceptualize 
the interdependencies, linkages, and power structures within a collaborative framework. These concepts can be applied to an "open system", "closed system", or "intersystem". The system intersystem model assumes that there is organization and interdependency, and some structure and stability.

An open system is a system that has connections with its environment. A boundary can be any demarcation, for example political, cultural, or geographic, that separates the system from its environment. The boundary that separates an open system from its environment is permeable so that there exists exchanges and contact between the system and its environment that can be measured. Woodlawn neighborhood itself, is an open system, although separated from the external environment (the city of Pawtucket) by a clearly marked neighborhood boundary. For example, Woodlawn residents interact with local government and URI, which are located outside of the Woodlawn boundary. Woodlawn residents may also interact with social service agencies that are also outside the Woodlawn neighborhood, such as Channel One in the City of Central Falls.

The intersystem model allows an examination of the dynamics of interdependency and interaction between and within the units of a system (e.g. subsystems). A basic intersystem model includes two open systems together. The Woodlawn neighborhood is an example of an intersystem model. Within the neighborhood there are multiple internal subsystems that are interdependent, such as the Woodlawn Neighborhood Association, Progresso Latino, and the 
Cape Verdean Association. The intersystem model has an advantage in that the change agent may remain removed, to some degree, as a resource of knowledge and as a facilitator of planned change (Bennis, Benne, Chin, 1976). It may also help in identifying the system for the change agent, and problems and barriers to change. The process of community empowerment is built upon the utilization of such support networks; particularly those that include the community as a partner in the network of internal systems.

The task of the change agent is to link these systems together, both internal subsystems and systems external to the Woodlawn environment. This includes bringing persons of knowledge and persons of action together through a process of creating linkages between conflicting groups toward collaboration (Bennis, Benne, Chin, 1976). These subsystems are linked by virtue of being located within Woodlawn, or may be linked outside the system by overlapping the Woodlawn boundary and interacting with outside resources. There may be social change agencies, neighborhood organizations, or government representatives such as community police or planning practitioners all with a similar goal of assisting residents. However, there may exist conflict or the potential for misunderstanding between these various subsystems. A new role of the change agent, in an environment that is filled with a plurality of voices, is to mediate change. With the multiple resources from which the change agent can draw upon, to create linkages, mediating the differences and minimizing the 
distortion in language is particularly important in facilitating the establishment of support networks.

Normative re-educative strategies of changing are aimed to change the values and institutional roles of individuals, organizations, or communities. Planned social change through normative re-educative strategies of change includes the "direct intervention by change agents, interventions based on a consciously worked out theory of change and of changing" (Bennis, Benne and Chin, 1976 pg. 22). The normative re-educative task of the change agent is to intervene mutually with the stakeholders to diagnose the relationships within systems and assess the problems that may lie with the norms and values of the stakeholders.

The collaboration of system components is a process of identifying problems as well as solutions and institutionalizing these support networks. The role of the change agent in this process is to introduce strategies of change within the system. Whether these strategies emphasize improving the problems solving capabilities of the system, or helping components of the system grow and develop. (Bennis, Benne, and Chin, 1976 pg. 33), the normative re-educative process of planned change emphasizes the re-education of system components. The role of the change agent in this process is, in part, to maintain an open line of communication and trust between persons, and emphasize a clear and barrierfree system. 
Analysis of COPC using Systems Analysis

The system model assumes that these parts of a system are integrated and that change is a result of the interdependency of these components (Bennis, Benne, and Chin, 1976). One of the organizing principles of the Woodlawn COPC is that by linking these subsystem components together, effective planned change can be accomplished. The intersystem model emphasizes the autonomy of the subsystem components and thus provides a tool to assess the cooperation or distinctiveness of these components. The role of the change agent is to facilitate the collaborative setting in which planned change occurs.

Community empowerment, as an instrument of planned change, is formed around the organization of community resources. Given the planning environment that the postmodern paradigm presents to the change agent, what are the possibilities of effective community empowerment? This analysis of the organization of the COPC with systems analysis will show how the facilitation of knowledge exchange is structured, and how learning takes place and revitalization strategies and activities are formed and implemented.

Robert Chin has described the intersystem model as "used to describe and analyze the relations of a system to an organized part of the environment, namely another system" (Bennis, Benne, and Chin, 1976 pg. 95). Each part of the Woodlawn COPC system can be conceptualized as a system-environment relation. Each component of this system interacts with the environment; the environment being those subsystems of COPC or any subsystem outside the 
organization of the Woodlawn COPC. A subsystem of the Woodlawn COPC (for example the Woodlawn Neighborhood Association) interacts with other subsystems of the COPC, or other systems outside the COPC organization. The Woodlawn COPC is structured to link these subsystem components, internal and external of the Woodlawn neighborhood, together. Within this structure, these subsystems are engaged in dialogue and discourse.

The postmodern approach to planning presents problems in the process of planned change. It emphasizes communication within a complex environment characterized by the lack of a single text and diverse interests of organizations and individuals as stakeholders in the decision-making process. The Woodlawn COPC is structured to bring the subsystems of the Woodlawn neighborhood together to form a new system that breaks down the barriers for change to take place and create new, open lines of communication. The Woodlawn COPC represents this structured system, and the URI UFC facilitates this dialogue and discourse among the multiple partners within it.

The direction of planning activities is complicated further by the imbalance of the power structure that is implicit in this environment. For example, the Woodlawn Neighborhood Association is a formally recognized neighborhood group of mostly homeowners. A renter organization in the Woodlawn neighborhood does not exist. The normative re-educative task of the URI UFC, as the change agent, is to facilitate a new relationship between two groups of individuals or organizations; to alter the normative relationships between these 
two subsystems. This process is aimed at re-orientating both the perception and cognitive knowledge of these subsystems (Bennis, Benne, and Chin, 1976).

The organizational structure of COPC represents discourse, tension, and feedback that culminates in change. This change is a new state of equilibrium. Subsystem components within the system may not communicate effectively or share common goals. From these tensions, stresses and strains may develop. Tension, however, is a major part of change for practitioners. The change agent operates within these tensions and strains within the system to help bring about planned social change. 


\section{Summary}

Community empowerment engages systems with dissemination strategies that involve connecting multiple systems together in a collaborative mode to share resources and transfer knowledge. A structured organization such as the Woodlawn COPC and URI UFC facilitates this network of subsystems. More importantly, the role of the URI UFC in this process is to facilitate this partnership.

The network of systems that have come together to form COPC have done so to revitalize the Woodlawn neighborhood. This involves, specifically, including various components of the Woodlawn system (e.g. neighborhood groups, residents, and social service agencies). This also includes systems outside the Woodlawn neighborhood (e.g. universities, practitioners, government agencies, and social service agencies). The interaction of these systems and the interdependency of these systems are formed by the structure of the COPC. The results are community-based research of issues, the creation and implementation of activities and plans, and educational outreach and resource distribution. This is accomplished by focusing on the participation and leadership of area residents. Residents are empowered through the establishment and operation of the Woodlawn COPC as a system of collaborative partners.

Each part of the system, whether they are individuals or groups, has resources and information to add to the process of revitalization. Residents or 
university faculty working in the neighborhood have knowledge they want to share, information they can contribute, and resources they can bring to the table. Through this process, people are empowered by not only gaining knowledge, but are empowered by being part of the process itself. By linking the systems together in an organized environment, the exchange of this knowledge and resources is more easily facilitated. A comprehensive and inclusive approach to revitalization can be accomplished. 


\section{CHAPTER FOUR \\ Woodlawn COPC Subcommittee Activities}

\section{Introduction}

The system of interdependencies the change agent must operate is an environment of plurality with persons of various technical expertise and knowledge. Resources and information exist within a turbulent, ambiguous and complex environment. The Woodlawn COPC has been organized as a system that includes such a diverse representation of subsystem components (e.g. Woodlawn residents, components of government, and universities). Its organization as a coalition of support institutions provides a framework from which community empowerment is carried out.

The development and implementation of revitalization strategies that engage and empower Woodlawn residents are formed from the experiences and knowledge of residents and involvement of COPC partners. The activities and programs of each subcommittee are the result of a consultation process between experts and professionals and Woodlawn residents in this consortium. This chapter details the activities of the Woodlawn COPC Housing Subcommittee, Planning and Neighborhood Revitalization Subcommittee, and the Education/Social Services Subcommittee. These subcommittees were formed from the Advisory Committee, and are chaired by Woodlawn residents, assisted by COPC staff and supported by participating agencies. The activities of these subcommittees are the core of the innovative approach to neighborhood revitalization that focuses on community engagement and empowerment. 
This partnership between local institutions, organizations, universities and local government has created a support network of resources. The consortiums of partners in each subcommittee that include these representatives share information and knowledge. These subcommittees are set up for action to take place. The URI UFC as the change agent facilitates this.

\section{Housing Subcommittee}

The needs that the Housing Subcommittee had focused on included increased homeownership, tenant/landlord education, helping to revitalize abandoned properties and dissemination on housing information. Given these issues, the Housing Subcommittee identified the following research areas and outreach programs:

- dissemination and training of Woodlawn residents concerning innovative forms and opportunities for home ownership and bank involvement;

- research of the HUD A.I. - Fair Housing Impediment Plan;

- workshops on cultural diversity and housing research behavior;

- computer skills training at Galego Court of the Pawtucket Housing Authority;

One activity that has emerged is the organization of the Housing Coalition and the Housing Support Committee. The Housing Coalition includes all the agencies that provide housing and social services in the Woodlawn neighborhood: City of Pawtucket Community Development Office, Pawtucket City Solicitor, renters, homeowners, Pawtucket Housing Authority, Woodlawn Neighborhood Association, Blackstone Valley Community Action Project and the 
Rhode Island Housing Network. The Housing Coalition was established to address the following:

(1) Identify and enact strategies to overcome social, cultural and aesthetic barriers to housing in the Woodlawn community

(2) Identify and enact incentives for home buyers to purchase and occupy houses in the Woodlawn area

A Housing Support Committee was also established to offer technical assistance to the Housing Coalition. This Committee includes: the University of Rhode Island Cooperative Extension Housing Specialist; University of Rhode Island Urban Field Center staff; The Roger Williams Law School; community residents; Pawtucket Housing Authority and the City of Pawtucket Zoning and Code Enforcement officer.

The Roger Williams law clinic researched six housing related topics selected jointly with neighborhood residents: "Community Reinvestment Act Compliance"; "Housing Standards and Enforcement"; "Housing Court Process"; "Lead Paint Reduction"; "Impediments to Fair Housing"; and "Homeownership Options". The following statements were made to the COPC Advisory Committee:

- Minimum housing standards laws applicable to Pawtucket residents

- The code enforcement and housing court process in Pawtucket

- Lead Paint lawns and procedures applicable to tenants living in Pawtucket

- Compliance by lending institutions in Woodlawn and Pawtucket with Community Reinvestment Act Requirements (a preliminary assessment)

- Forms of how ownership available and appropriate for Woodlawn

- Barriers to fair housing in Pawtucket 
Board members of the Housing Subcommittee wanted to research, specifically, some of the housing issues that were important to residents. The Housing Coalition Subcommittee targeted access to opportunities which exist in homeownership. The Housing Subcommittee, with the help of the URI UFC, developed a survey that was distributed to Woodlawn residents and residents of the Pawtucket Housing Authority. The results indicated that the majority of respondents were not aware of opportunities for home ownership and how they could access the information.

Another activity coordinated by the Housing Subcommittee was the Woodlawn Housing Festival. This was the result of the community-based research conducted by the housing subcommittee and The Roger Williams Law School Practicum Classes. The Housing Subcommittee, with the assistance of those partners in the Housing Coalition and Advisory Committee, co-sponsored the Woodlawn Housing Festival. This activity was the result of universitycommunity working together by exchanging information, conducting research and building community empowerment through outreach.

The purpose of the Woodlawn Housing Festival was to provide information on home ownership opportunities in the Woodlawn neighborhood as well as other relevant knowledge, which would help create a safer, healthier, living environment. It was a four-hour festival held at Slater Junior High School in Woodlawn. Representatives came from: Citizens Bank; the Blackstone Valley Community Action Project; URI Cooperative Extension; Narragansett Electric; 
Community Lead Action Project; and Pawtucket City Government departments such as Planning and Redevelopment, Code Enforcement, and the Community Police Unit, as well as other area agencies. All provided literature and resources, answered questions, and made themselves available to the community. The Housing Festival also had workshops facilitated by representatives from lending institutions and State and City agencies. These workshops included:

- "Home Buyer Assistance" conducted by the Blackstone Valley Community Action Project (BVCAP)

- "Credit Counseling/Budget Management" conducted by RI Consumer Credit Counseling Service

- "Childhood Lead Paint Project" conducted by RI Department of Health

- "Lead Poisoning Prevention and Awareness" conducted by Childhood Lead Action Project

- "Home Neighborhood Safety" conducted by Pawtucket Community Police Unit "Home Repair Program" conducted by the City of Pawtucket Planning and Redevelopment. 


\section{Neighborhood Revitalization and Planning Subcommittee}

Issues of residents in Woodlawn identified under the neighborhood revitalization and planning category were the lack of clean, open space, and the poor condition of neighborhood parks. Strategies that where suggested for revitalization activities included: community organizing and neighborhood awareness and redesigning the urban parks and upgrading the infrastructure in and around recreation areas including increased housing code enforcement and sanitation.

One of the priority issues identified by area residents was the need to build the organizational capacity of Woodlawn residents. This included strengthening the leadership capacity of community based organizations and residents in Woodlawn to organize around community needs, design community projects and become more self-sufficient. The Woodlawn Neighborhood Leadership Institute and the Advanced Woodlawn Neighborhood Leadership Institute where developed to provide training to local residents and neighborhood groups in leadership skills, and provide information and to make available resources that build the capacity of local leaders and potential organizers.

The purpose of the Basic Woodlawn Neighborhood Leadership Institute was to provide information to area residents and agencies on the opportunities for becoming more involved in the Woodlawn neighborhood, and educate residents on what the neighborhood has to offer. The Leadership Institute was a 
series workshops that that took place once a week for six weeks. The goal of the Leadership Institute was to involve the participants in an interactive setting and educate them on a number of subjects.

The Advanced Leadership Institute followed a similar format of the basic Leadership Institute, but offered workshops that focused on skill development. A different topic was covered each workshop. These topics included: "Orientation" as an ice breaking activity; "Diversity Development" to train in diversity and offer skills in collaborating with neighbors and building better relationships; "Community Outreach Strategies" to build skills in identifying community issues and utilizing strategies of community organizing and coalition building; "Mediation and Negotiation in Action" includes training in effective conflict resolution techniques and effective styles of communication; "Grant Writing Parts I and II" providing the basics of fundraising, identification of funding sources, the RFP process, and the fundamentals of writing a proposal; "Your State Government in Action" to raise awareness of the legislative process, how issues are identified and how a bill becomes a law; "Community Service Project and Graduation" provides a chance for Institute participants to create a group project utilizing several of the skills that they learned and to develop a group community project which gives them leadership in Woodlawn as well as an opportunity to transfer the knowledge they learned to other residents of Woodlawn. 
Each workshop featured a different facilitator and or representative from either an agency or as an active community member. For example, the Code Enforcement Officer for the City of Pawtucket discussed housing codes and the issue of sanitation removal. URI Cooperative Extension trained in Diversity awareness; a community activist trained in community outreach strategies; the Providence Community Mediation Center utilized trained community mediators to train Institute participants in conflict resolution techniques. 


\section{Education Subcommittee}

Issues identified under the Education/Social Services category included the expansion of the adult literacy program, especially for the learning of English; the need for "before and after" school activities; the need to make the public schools more accessible to parents; and the need to address racial and ethnic sensitivity issues. Strategies that were identified include: support to local students to enter post-secondary education through program development and educational outreach that addressed the use of schools after hours, child-care programs, parenting skills, and culture sensitivity.

Besides providing resources for community-based research to be carried out, the Woodlawn COPC is designed to provide programming and information dissemination to Woodlawn residents. These programs are specifically designed to link higher education with the Woodlawn community. The programming activities that the Education Subcommittee is involved with include activities of the URI Guaranteed Admissions Program (GAP), the Cunningham/Slater Child Opportunity Zone/Family Center, the Pawtucket School Department, and the URI/Pawtucket Schools Service Learning Initiative. The role of the Education Subcommittee in these activities is to provide guidance to the partners of the Woodlawn COPC activities and to determine appropriate programming to address the needs of the community. The members of the Education Subcommittee give advice on the implementation of programs and advise on how to improve existing activities. The members of the Education Subcommittee also 
develop new programs in response to a need not being met by the partners in the COPC. These critical partners in the Education and Social Services category include staff from the Pawtucket Child Opportunity Zone, URI GAP, and URI Cooperative Extension.

The program activities of the Cunningham/Slater Child Opportunity Zone $(\mathrm{COZ})$ in Woodlawn have been developed in response to the issues identified by the Education and Social Services Subcommittee and Woodlawn residents. The Pawtucket $\mathrm{COZ}$ office has access to the minority population and limited English speaking residents in Woodlawn by targeting the parents of children in the school. It also provides an integrated social service support system. This includes making referrals based upon needs, for families and children from Cunningham and Slater Junior High Schools. The Pawtucket COZ also offers after school programming that includes academic and recreational activities. The Pawtucket COZ works closely with URI Cooperative Extension to train parents in effective parenting skills.

The URI Guaranteed Admissions Program (GAP) is another program that provides a resource to Woodlawn residents. The GAP program increases the opportunities of students from Shea High School and Tolman High School to enter into higher education. The GAP program exposes High School students to higher education and guides them towards college readiness. An important component of the GAP program is the presence of an on-sight coordinator. The 
Education and Social Services Subcommittee takes part in the development of activities of the GAP program.

The Education and Social Services Subcommittee has also been involved in building an action plan for the Pawtucket school district. The Rhode Island State Department of Education requires this action plan for every school district in the state. One component of this action plan is the creation of a "one-stop" center for students and parents. Currently, there is no facility in Pawtucket that serves all of the various needs of school children and parents in one location. A one-stop center will serve a multi-functional role by providing an integrated school services program. The role of the Education Subcommittee is to implement this portion of the action plan. This requires building support for the idea and generating funding.

The Woodlawn community and the University of Rhode Island are also linked through the activities of the Service Learning Project. Service Learning is a collaborative undertaking between the University of Rhode Island and the Pawtucket School system. It is modeled after the West Philadelphia Improvement Corps (WEPIC) developed by the University of Pennsylvania. The goal of this project is to utilize the resources of higher education by linking them with Pawtucket Public Schools. This program provides an opportunity for the University of RI to develop curriculum with a service learning component which links undergraduate students with middle school faculty and students at Slater J. High School. At the public school level service learning activities are 
developed to link students from elementary, middle, and high schools in Woodlawn in programs such as reading and tutoring. URI UFC is currently discussing the possibility of linking the URI Nursing program with Slater Jr. High School's new Health Clinic. Plans are also underway for a Service Learning Institute for $7^{\text {th }}$ and $8^{\text {th }}$ graders at Slater Jr. High. 


\section{Summary}

The URI UFC facilitates activities of the subcommittees that research issues, coordinate outreach, and exchange information and resources. Residents are active participants. They are members on these committees along with professionals, academics, and practitioners. Through this system, information and resources are exchanged, support structures for neighborhood revitalization are created, and public services projects, capacity building, and instructional programs are developed. The structure of the COPC is a model for community empowerment.

The revitalization of the Woodlawn neighborhood undertaken by the Woodlawn COPC is a comprehensive approach. For example, the Education and Social Services Subcommittee actively participates in the design and implementation of the activities and program development of these COPC initiatives. The subcommittee is represented in the URI GAP program, Pawtucket COZ, the Pawtucket Schools Action Plan and the Service Learning Project. These programs are designed to link the University of Rhode Island with the Woodlawn Community. The activities that these programs support utilize university resources, such as URI Cooperative Extension, that facilitates the revitalization of Woodlawn. The educational component of the revitalization effort is supported by utilization of these university resources that are based in the community. 


\section{CHAPTER FIVE \\ Community Empowerment As A Strategy Of Planned Change: An Analysis Of The Woodlawn COPC Subcommittee Activities}

\section{Introduction}

In "Participatory Action Research," or "PAR," communities are actively involved in the research process. Participatory Research is a reaction to the positivist paradigm often held by universities in university-based research (Park, 1993). In traditional-based research in a community, knowledge that would benefit the researcher was the foremost objective and driving force behind the research (Nyden, 1997). New approaches of academic based research in communities have emphasized the participatory role that community residents play in the process of community research.

The research, activities, and programs that have been developed by the Woodlawn COPC Subcommittees and coordinated by the Woodlawn/URI COPC Partners is an inclusive and comprehensive approach to neighborhood revitalization. The cornerstone of these activities is the active participation of Woodlawn residents and the engagement in the community. The process of designing and implementing the objectives of the subcommittees, and the active engagement of these subcommittees result in community empowerment.

This chapter analyzes the work of the Woodlawn COPC, specifically the activities carried out under the three functional areas of: Housing; Planning and Neighborhood Revitalization; and Education/Social Services. Community empowerment has been achieved through capacity building of residents with 
strategies of participatory research; educational outreach; and resource distribution. This chapter will explore how these activities conform to the strategies of participatory research and outreach models, and will show how community empowerment is facilitated through research and outreach. This chapter will also answer the following questions: How does information become knowledge? And, how is this knowledge used towards community empowerment? 
Analysis of the Housing Subcommittee

The Housing Festival is an example of outreach and education and a normative re-educative strategy of planned change. The Housing Support group along with other agencies and department representatives provided literature and resources on topics such as opportunities for home ownership, financing assistance, and lead paint removal. Through this outreach activity, Woodlawn residents were presented with a "one stop" opportunity to learn more about the housing issues in Woodlawn, and understand the opportunities that exist to assist them with their housing needs.

Community empowerment is facilitated through the transfer of knowledge. This was accomplished by utilizing people with experience on housing issues. Resources where shared and information provided by these partners by actively engaging the community through outreach. The Housing Coalition, with the assistance of Housing Subcommittee members and facilitated by staff from the URI UFC, took on an active role.

This festival is also an example of community-based research. During the formation of the Woodlawn COPC, residents of agencies serving Woodlawn were asked to identify housing issues in Woodlawn that need to be addressed. Housing affordability was a priority for residents. Local residents identified issues such as this, and with the help of experts and professionals in the housing field, were able to disseminate information to the public. Staff members from the URI UFC assisted the Housing Subcommittee in developing the 
questionnaire. Community empowerment is facilitated by these research activities with the community rather than to the community so community residents may increase their knowledge of how research is performed and replicate it themselves. Residents also were involved by sharing what they knew to be perceived as issues, courses of action, and possible activities that might help to address the issues.

How does this represent empowerment in the postmodern paradigm? The master narrative is not used, but rather, people gain information from resource distribution and educational outreach from their partners. Through this, residents can make more informed decisions. It expands their knowledge of how to address issues such as a lack of home ownership and lead paint. Residents are not planned for, but are part of the planning process. 
Analysis of the Planning and Neighborhood Revitalization Subcommittee

The activities of the Community Planning and Revitalization

Subcommittee represent community empowerment by providing the community with the tools that can be used to conduct their own research and develop strategies for organizing around these issues. These activities build residents knowledge of resources that can be utilized to empower themselves. The process of developing revitalization strategies includes residents. A major focus of this research and strategy development was consultation and advisement from Executive Committee members and residents.

Capacity Building is a major tool of community empowerment. The Woodlawn Neighborhood Leadership Institute represents the process of community empowerment by providing the community with the capacity to utilize their skills to conduct research on issues, and organize and develop strategies to resolve these issues. These activities engage residents and build their knowledge of resources and opportunities. The process of developing revitalization strategies and including residents in the planning process provides residents with an opportunity to not only learn skills, but to include their own perspective in the process. Residents took part in the development of revitalization strategies for the URI Community Planning Studio Project, the "Woodlawn Neighborhood Revitalization Strategy Report" and the URI Landscape Architecture gateway and streetscape study and the revitalization of 
Payne Park. Residents are considered part of the process, not the "client" or object.

Analysis of Education / Social Services Subcommittee

The activities of the Education and Social Services Subcommittee represent resource building in the Woodlawn neighborhood. The members of the subcommittee where involved in the process of program design and implementation. The network of COPC partners who provide community based information dissemination and outreach supports their involvement in this process. Together with practitioners, academics, and professionals, community residents are involved with the comprehensive approach to neighborhood revitalization.

The activities of the Woodlawn COPC Education Subcommittee are a model of collaboration between persons with knowledge. The process of resource outreach is the utilization of the sources of knowledge and organizing them under the principles of COPC. These principles are grounded in the utilization of community and university resources to provide programs and activities to empower residents.

The GAP program has been designed to provide access to higher education by expanding opportunities for students to prepare themselves for college. The Service Learning Initiative also links university to community schools by offering opportunities for faculty and students to engage in academically 
oriented activities that provide an outlet for the transfer of knowledge and turning that into action oriented community activities. Service Learning activities provides higher education students with learning experiences that go beyond classroom learning into communities. The Middle school students are empowered by building their self-esteem, increasing their skill level, and giving them a sense of accomplishment. All of these combined are proven to increase the academic level and social character of inner city students.

A collaborative network of agencies fosters the facilitation of learning. The process of learning for parents and students is not mutually exclusive, but together form the activities of the programs identified in this section. Parents are encouraged to participate and become more involved in planning and implementing strategies for learning. A focus on community-based schools emphasizes the inclusion of community resources, such as parents, in the development of both educational and community service project. 


\section{Summary}

In community based research, "knowledge becomes a crucial element in enabling people to have a say in how they would like to see their world put together and run" (Park, 1993 pg. 3). Through community participatory research, communities are actively and continuously involved in the research process. By this, community residents are empowered through the provision of resources, skills, and tools that are needed to carry out research (Nyden, 1997). In collaborative partnerships, such as the Woodlawn COPC, knowledge is transferred between university and community through research based activities. In this type of research that is conducted by the partners, the information or knowledge each partner has is shared (Nyden, 1997).

The Woodlawn/URI Community Partnership, as a collaborative framework between community and university, facilitates community empowerment through the activities that are organized by the subcommittees. It is within this university-community partnership that knowledge is exchanged which aims to empower community residents and build their capacity. This knowledge exchange takes place through participatory research and information provision and resource outreach. These two concepts demonstrate how the activities of the Woodlawn/URI COPC facilitate community empowerment.

The role knowledge plays in planned change has moved away from strictly a positivist approach of legitimization of knowledge and action towards the direct inclusion of the experiences and inputs of those involved (Nyden, 1997). 
This is of significance to the practice of planning in the post-modern paradigm. The knowledge of the expert in the process of planned change (e.g. facts of the normative value related approach), and the inclusion of the knowledge of those that are involved in the planning process, creates a particular dichotomy (Innes, 1990). Knowledge of residents, academics and professionals is valid in the decision making process. The role of the modern paradigm is goal oriented and client centered (Gans, 1991; Innes, 1990), with the role of the planner as being a technician and expert in a non-political position. In this modern position, the planner attempts to define a single public interest, but in the process, ignores various sources of knowledge. The postmodern approach to planning has shown the inadequacies of the rational model of decision-making, and utilizing the postmodern approach has refocused the process of planning. 


\section{CHAPTER SIX \\ Conclusion: \\ Community Empowerment As A Link Between Theory And Practice}

\section{Introduction}

Collaborations are formed because people share the same values, goals, or common interests. Collaboration is seen as a solution, not just a process. The community research and outreach strategies undertaken by the Woodlawn COPC had included community members from beginning to end. Residents and community organizations and agencies are members on the subcommittees, which determine COPC action. These community members took part in data collection for their research project and coordinated outreach, education and resource dissemination with their activities. Community empowerment was achieved by residents actively participating in these activities (e.g. developing and implementing revitalization plans) and receiving information by agencies who provided resources and capacity building.

Through the Woodlawn Neighborhood Leadership Institute and other collaborative community research activities, residents not only became more familiar with revitalization efforts undertaken by the Woodlawn COPC, but also increased their knowledge of neighborhood issues and expanded their knowledge of opportunities to help themselves. As each organization described above is part of the system in Woodlawn, individuals are part of the social network of community and neighborhood. The meta-narratives of the modern paradigm are not sufficient to articulate and represent the vast interests and experiences of 
each individual of the social system. Through community empowerment, Woodlawn residents can themselves organize, become leaders, expand their opportunities, and educate others.

\section{Findings}

This thesis project has specifically explored the structure of the Woodlawn Community Outreach Partnership Center, and examined the activities of the three subcommittees on housing, planning and neighborhood revitalization, and education and social services. The purpose of this project has been to establish a link between the theory of the postmodern planning paradigm and the action of planning. This relationship is community empowerment. Community empowerment is grounded in collaboration and partnerships. This research concludes with three important findings.

First, the structure of the Woodlawn COPC facilitates community empowerment. Community empowerment can be understood as an outcome and a process. It is realized when people or organizations can themselves make decisions with new knowledge, and are able to turn knowledge to action by participating in the process of change. This can be accomplished through community based research and resource outreach and information dissemination. The Woodlawn COPC is structured to accomplish these goals. The subcommittee activities are an example of how these goals are met. For example, the Housing Subcommittee organized the Housing Festival around 
issues identified by residents. Research was conducted on housing issues and information was disseminated to Woodlawn residents, by Woodlawn residents and organizations. Residents also identified issues related to education, and have helped to coordinate the activities of the URI Gap program, Service Learning program, and Pawtucket COZ. The Woodlawn COPC demonstrates how community empowerment is accomplished through a structured partnership where community residents take part in research activities, and both receive and assist in dissemination of information that addresses issues that where selfidentified.

Second, this participatory activity of Woodlawn residents in the comprehensive revitalization effort of their neighborhood is significant given the postmodern planning environment. This environment emphasizes the plurality of voices in a complex and ambiguous setting that poses problems of consensus building and goal setting. By gaining knowledge that will help them in this environment, Woodlawn residents can conduct research, organize around issues as a community or individually, and direct planning activities themselves. The Advanced Neighborhood Leadership Institute is an example of how Woodlawn residents gained information on how to conduct research, write grants, and mediate conflict. They also took part in a community revitalization project, utilizing the skills they acquired. Activities, such as the Leadership Institute, is a way for Woodlawn residents to gain information so that they may reposition themselves within the postmodern planning environment. 
Third, planned social change in the postmodern planning environment is achieved through the facilitation of a change agent. The normative re-educative role of the change agent is to facilitate knowledge exchange by bringing persons of knowledge together in a collaborative setting. The URI Urban Field Center, as the change agent, has facilitated the development of a network of resources that are used in the process of empowering residents. These partners are brought together under a structured organization of the Woodlawn COPC to share knowledge, provide resources, outreach, and disseminate information. The URI UFC facilitates these activities by mediating the process of change; minimizing language distortion, and maintaining a barrier free setting with open lines of communication. The establishment of this collaborative network is required of planned social change. The Woodlawn COPC is an example of such a partnership between agencies that not only share resources, but also include community residents as resources in the process of change.

Community empowerment is a link between the postmodern planning environment and the action of planning. The structure of the Woodlawn COPC facilitates the exchange of knowledge through community based research activities and information dissemination. These are reflected in the activities of the COPC committees that demonstrate the process of community empowerment. They involve residents in the decision making process by utilizing residents knowledge and input to help direct planning activities, and residents are empowered by being able to assist in revitalization activities as 
well as gain information they can use to reposition themselves within society. Community empowerment, is therefore, a strategy of planned social change in the postmodern planning environment. People do not have to rely on activities of the modern paradigm, but can use what they have learned to turn knowledge to action to achieve planned social change. 


\section{Summary}

The purpose of this thesis project has been to examine the links between theory and practice through an examination of collaborative partnerships and the emergence of community empowerment as a bridge between the theory of the postmodern paradigm and the practice of planning. Community empowerment as a tool of planned social change was explored within the normative re-educative model of planned change described by Bennis Benne and Chin (Bennis, Benne, and Chin, 1976). Under this approach, the role of the change agent is a facilitator and mediator. Linkages are emphasized where theory and knowledge are legitimized in a collaborative model, and the transfer of information as knowledge takes place through capacity building and empowerment.

The structure of the URI/Woodlawn Community Partnership displays this approach to community empowerment. Organizing community support by building systems provides a way to facilitate planned social change. The process of creating support systems through facilitating the communication between institutions and organizations functions as an empowerment tool - changing powerlessness to empowerment and action. 


\section{WORKS CITED}

Alexander, Ernest., Approaches to Planning: Introducing Current Planning Theories, Concepts, and Issues. New York: Gordon and Breach Publishers. 1990.

Alinsky, Soul. Reveille for Radicals. New York.: Random House, 1969.

Argyris, Christopher. Intervention Theory and Method. Mass.: Addison-Wesley, 1970.

Beauregard, Robert A., (1989), "Between Modernity and Postmodernity: The Ambiguous Position of U.S. Planning." in Environment and Planning: Society and Space. Vol. 7, pp.381-395.

Robert A. Beauregard, Robert A., (1991). "Without a Net: Modernist Planning and the Postmodern Abyss" in JPER Vol.10, No.3.

Bennis, Benne, Chin, and Corey, The Planning of Change, $3^{\text {rd }}$ ed., NY: Holt, Rinehart, and Winson, 1976.

Buber, Martin. Paths in Utopia. London. Routledge and Kegan Paul, 1949.

Butterfoss, F. D., Goodman, R. M., and Wandersman, A., (1993). "Community Coalitions for Prevention and Health Promotion". Health Education Research, Vol.8 No. 315-330.

Carmichael, Stohlley., and Hamilton, C. Black power: The politics of liberation in America. New York: Random House, 1967.

Chavis, D.M., Florin, P., and Felix, M.R.J. (1993). "Nurturing Grassroots Initiative for Community Development: The Role of Enabling Systems". In T. Mizrahi and J. Morrison, (Eds.), Community Organization and Social Administration (pp.41-67). New York: Haworth.

Chavis D. M., and Wadersman, A. (1990) "Sense of Community in the Urban Environment: A Catalyst for Participation and Community Development". American Journal of Community Psychology, Vol.18, 55-81.

Chavis D., and Florin, P. (1990) Community Development Community Participation and Substance Abuse Prevention. San Jose, CA: Santa Clara County Department of Health. 
Chin, Robert., "The Utility of System Models and Developmental Models for Practitioners". in The Planning of Change. (Ed). Bennis, Benne and Chin. $3^{\text {rd }}$ ed., NY: Holt, Rinehart, and Winson, 1976.

Crowfoot, James E. and Chesler, Mark A. (1974) "Contemporary Perspectives on Planned Social Change: A Comparison". The Journal of Applied Behavioral Science Vol. 10, No.3 pp. 278-303.

Culbert, Samuel A., “ Consciousness-Raising: A Five Stage model for Social and Organizational Change" in Theories of Group Process (Ed.) Cary L. Cooper (1975) (also printed in Bennis, Benne, and Chin, 1976)

Eiser, Arlene, (1994) "Survey of Neighborhood-Based, Comprehensive Community Empowerment Initiatives" Health Education Quarterly Vol.21 No.2 pp. 235-252.

Eng, Eugenia,. and Parker, Edith. (1994) "Measuring Community Competence in the Mississippi Delta: The Interface Between Program Evaluation and Empowerment". Health Education Quarterly. Vol.21 No.2 pp.199-220.

Evan, W.M. (1966), "The Organization Set: Toward a Theory of Interorganizational Relations" in J.K. Thompson (Ed.), Approaches to Organizational Design, University of Pittsburgh Press.

Fairfield, R. Communes, U.S.A. Baltimore: Penguin Books, 1972.

Fawcett, S.B., Paine, A.L., Francisco, V.T., and Vliet, M. (1993). "Promoting health through community development". In D. Glenwick and L.A. Jason (Eds.), Promoting Health and Mental Health: Behavioral Approaches to Prevention. New York: Haworth.

Fawcett, Stephan B., et al. (1995) "Using empowerment Theory in Collaborative Partnerships for Community Health and Development". American Journal of Community Psychology Vol.23 No.5 pp.677-698

Forester, John, Planning in the Face of Power Berkley: University of California Press. 1989.

Fromm, E. Man for Himself. New York: Rinehart and Co., 1947.

Gamson, W. Power and Discontent. Homewood, Ill.: Dorsey Press, 1968.

Gans, Herbert, People, Plans and Policies. New York: Columbia University Press and Russell Sage Foundation. 1991. 
Gabor, A, The Man Who Discovered Quality. New York: Time Books. 1990.

Gilbert, N., and Eaton, J.W., (Nov.1970) "Who speaks for the Poor?" Journal of the American Institute of Planners, Vol. 36, No.6, (also printed in Bennis Bean and Chin )

Gray, B. Collaborating: Finding Common Ground for Multiparty Problems. San Francis: Jossey-Bass. 1991.

Harvey, David. The Condition of Postmodernity. Mass: Blackwell Press. 1990.

Hemmens, George., (1992). "The Postmodernists Are Coming, the Postmodernists Are Coming." Planning Magazine

Innes, Judith., Knowledge and Public Policy. $2^{\text {nd }}$ ed.. New Brunswick: Transaction Publishers. 1990.

Isreal, Barbara A., Checkoway, Barry., Schulz, Amy., Zimmerman, Marc., (1994) "Health education and community empowerment: Conceptualizing and measuring perceptions of individual, organizational, and community control in health." Health Education Quarterly Vol.21 No.2 pp.149-170.

Kahn, S. How people get power. New York: McGraw-Hill, 1970.

Labonte, Ronald., (1994) "Health Promotion and empowerment: Reflections on professional practice" Health Education Quarterly. Vol.21 No.2 pp.253-268.

Levine, S., and White, P.E. (1961), "Exchange as a conceptual framework for the study of inter-organizational relationships”, Administrative Science Quarterly, Vol.5 pp. 583-601.

Likert, R. New Patterns of Management. New York: McGraw-Hill, 1961.

Lippit, R., Watson J., and Westley, B. The Dynamics of Planned Change. New York: Harcourt and Brace, 1958.

Litwak E., and Hylton, L. (1962), "Inter-organizational Analysis: a Hypothesis on Coordinating Agencies", Administrative Science Quarterly, Vol.6 pp.395-420.

Lyotard, Jean-Francois. The Postmodern Condition: A Report On Knowledge. Minneapolis: University of Minnesota Press. 1984.

Mandelbaum, Seymour J., (1991). “Telling Stories” JPER Vol. 10 No, 3. 
Maton, Kenneth I., Solem, Deborah A., "Organizational Characteristics of Empowering Community Settings: A multiple case study approach". American Journal of Community Psychology. 1995 Vol.23 No.5 pp. 631-656.

McCarthy, J.D., and Zald, M.N. (1977). "Resource mobilization and social movements: A partial theory". American Journal of Sociology, vol.82, pp.12121241.

McMillan B., Florin P., Stevenson J., Kerman B., Mitchell R. E., (1995) "Empowerment praxis in community coalitions". American Journal of Community Psychology Vol.23 No.5 pp.699-728

Milroy, Beth Moore., (1991) "Into Postmodern Weightlessness" JPER. Vol. 10, No.3.

Mondros, J.B., and Wilson, S. M., Organizing for Power and Empowerment. New York: Columbia University Press. 1994

Nearing, S, and Nearing, H. Living the good life. New York: Schocken Books, 1970.

Nyden, Philip, Figert, Anne, Shibley, Mark, Burrows, Darryl., Building Community: Social Service in Action. California: Sage. 1997

Paris, Chris., Critical Readings in Planning Theory. New York: Pergamon Press. 1982

Peattie, Lisa R. "Drama and Advocacy Planning", (1970) Journal of the American Institute of Planners Vol. 36, No. 6, pp. 405-410. (also printed in Bennis, Benne, and Chin 1976)

Perkins, Douglas D., Zimmerman, Mark A. (1995) "Empowerment theory, research, and application", American Journal of Community Psychology. Vol.23 No.5 pp.569-580.

Perkins, Douglas D., and Brown, Barbara B., "The Ecology of Empowerment: Predicting Participation in Community Organizations." Journal of Social Issues. vol.52 n.1 pp.85-110 1996.

Plaugh, Alonzo,. And Olafson, Freya. (1994) "Implementing the Boston Healthy Start Initiative: A Case Study of Community Empowerment and Public Health." Health Education Quarterly. Vol.21 No.2 pp.221-234. 
Potapchuk, William R., (1996) "Building Sustainable Community Politics: Synergizing Participatory, Institutional, and Representative Democracy. National Civic Review, Vol.85, No.3 pp. 54-60.

Rappaport, J. (1981) "In Praise of Paradox: A Social Policy of Empowerment Over Prevention". American Journal of Community Psychology, Vol.9, pp.1-25.

Rich, Richard C., Elelstein M., Hullman, William K., Wandersman, Abraham H., (1995) "Citizen Participation and Empowerment: the Lure of Local Environmental Hazards". American Journal of Community Psychology Vol.23 No.5 pp. 657-676.

Sarason, S.B., and Lorentz, E. The Challenge of the Resource Exchange Network. San Francisco: Jossey-Bass. 1979.

Schein, E. Process Consultation: Its Role in Organizational Development. Reading, Mass.: Addison-Wesley, 1969.

Schutz, W. Here Comes Everybody. New York: Harper and Row, 1971.

Schoen, Donald., The Reflective Practitioner: How Professionals Think in Action. NY: Basic Books, 1982.

Slater, P. The Pursuit of Loneliness: American Culture at the Breaking Point. Boston: Beacon Press, 1970.

Swift, C., and Levin, G. (1987). "Empowerment: and Emerging Mental Health Technology". Journal of Primary Prevention, Vol.8, pp.71-94.

Spreitzer, Gretchen M. (1995) "An Empirical Test for a Comprehensive Model of Interpersonal Empowerment in the Workplace", American Journal of Community Psychology. Vol.23 No.5

Spreitzer, Gretchen M. (1992) "When Organizations Dare: the Dynamics of Individual Empowerment in the Workplace". Unpublished Doctoral Dissertation, Univ. of Michigan Ann Arbor

Spreitzer, Gretchen M. (1995), "Psychological Empowerment in the Workplace: Dimension Measurements and Validation". Academy Management Journal. Vol.38, pp.1442-1465.

Thomas, Michael J., "The Procedural Planning Theory of A. Faludi" in Critical Readings in Planning Theory. New York: Pergamon Press. 1982. 
Thompson, J.d. and McEwen, W.J. (1958), "Organizational Goals and Environment”, Psychological Review, Vol. 42, pp.43-72.

Wallerstein, Nina., and Bernstein, Edward., (1994) "Introduction to Community Empowerment, Participation, education, and Health" Health Education Quarterly Vol.21 No.2 pp.141-148.

Watson, G. "Resistance to Change". In G. Watson (Ed.):Concepts for Social change. Washington, D.C.: National Training Laboratokies, 1966.

Weick, K.E. (1984). "Small Wins: Redefining the Scale of Social Problems". American Psychologist, Vol.39, pp.40-49.

Wilson, Patricia A., (1996) "Empowerment: Community Economic Development from the Inside Out”. Urban Studies. Vol.33 No.4-5 pp. 617-630.

Wolff, T. Coalition Building: One Path to Empowèred Communities. Amherst, MA: Community Partners. 1992.

Zimmerman, M.A., (1995). The Measurement of Psychological: Issues and Strategies. American Journal of Community Psychology, Vol.23 pp.581-599

Zimmerman, M.A. (1993). "Empowerment Theory: Where Do We Go From Here". Paper presented at the annual meeting of the Midwest Psychological Association, Chicago, Il.

Zimmerman, M.A., Israel, B.A., Schulz, A., and Gheckoway, B. (1992). "Further Explorations in Empowerment Theory: An Empieal Analysis of Psychological Empowerment". American Journal of Community Psychology, Vol.20, 707-727.

Zetterberg, H. Social Theory and Social Practice. Towata, N.J.: Bedminister Press, 1962. 